\title{
Phosphate Rock Dissolution and Availability in Some Soils of Semi-deciduous Rainforest Zone of Ghana
}

\author{
S. K. Asomaning ${ }^{1}$, M. K. Abekoe ${ }^{1 *}$ and E. Owusu-Bennoah ${ }^{2}$ \\ ${ }^{\prime}$ Department of Soil Science, University of Ghana, Legon-Accra, Ghana \\ ${ }^{2}$ Council for Scientific and Industrial Research, P. O. Box M.32, Accra, Ghana \\ *Corresponding author; E-mail: k_abekoe@ug.edu.gh
}

\begin{abstract}
Alfisols and Ultisols of the semi-deciduous forest zone of Ghana are known to be moderately acid and very low in plant available phosphorus (P). These soils need to be fertilized to increase crop production but due to economic reasons local farmers are unable to afford water-soluble P fertilizers. Instead of expensive superphosphates, the use of less expensive phosphate rocks such as Togo rock phosphate (TRP), Gafsa rock phosphate (GRP) and 50\% partially acidulated rock phosphate (PAPR) are possible alternative P sources for these soils. The rate of dissolution of TRP, GRP, PAPR and TSP in three benchmark soils of Ghana was assessed, and the effectiveness of these P sources determined in a greenhouse using maize (Zea mays var. Toxpino) as a test crop. The dissolution of the $\mathrm{P}$ sources in three soils Bekwai, Nzima (Ultisols) and Kokofu (Alfisol) along a toposequence was investigated in an incubation study and also in a greenhouse experiment. The rate of dissolution of the $\mathrm{P}$ fertilizers was determined in the laboratory by extracting with anion exchange resin membrane (AEM), $0.1 M \mathrm{NaOH}$ and $1 M \mathrm{HCl}$ at 21 days interval for 105 days. In the greenhouse study, each $\mathrm{P}$ source was added at the rate of $60 \mathrm{mg} \mathrm{P} \mathrm{kg}^{-1}$ soil, and sown to maize (Zea mays. var.Toxpino) for 28 days. The results of the incubation study showed that the amount of $\mathrm{P}$ extracted by the AEM and $\mathrm{HCl}$, following the addition of the $\mathrm{P}$ sources, decreased with incubation time in all three soils. However, there was an increase in $\mathrm{NaOH}-\mathrm{P}$ in all the three soils as incubation progressed. The increase in the NaOH-P suggested that the dissolved $\mathrm{P}$ was adsorbed by Fe and Al oxides. The greenhouse results showed that dry matter yield was in the order $\mathrm{TSP}=\mathrm{PAPR}>\mathrm{GRP}>\mathrm{TRP}$. Relative to TRP, the PAPR and GRP were reactive enough to provide plant available P to satisfy the early $\mathrm{P}$ requirement for maize growth. Togo $\mathrm{PR}$ has little potential for direct application in the three soils.
\end{abstract}

\section{Introduction}

Food production in the semi-deciduous rainforest zone of Ghana is limited by low soil fertility. Phosphorus deficiency has been identified as one of the major soil fertility constraints in the soils (Owusu-Bennoah et al., 2000). Many small-scale farmers in the zone find it increasingly difficult to afford water-soluble commercial $P$ fertilizers because of high cost. Hence, the need to increase crop production with less expensive indigenous phosphate rocks (PRs) merits the attention of local researchers. Large deposits of phosphate rock exist in West Africa (McClellan \& Notholt, 1996), and their application to increase crop production has been investigated with varying degree of success (Khasawneh \& Doll, 1978; Hammond, et al., 1986; Sale \& Mokwunye, 1993).

Two major factors are generally recognized as influencing $\mathrm{P}$ availability from phosphate rocks: (i) inherent differences among PR sources, and (ii) soil properties (Smyth \& Sanchez, 1982). Thus, the usefulness of these PRs to farmers will depend on their dissolution patterns and availability of the released P. The solubility of $\mathrm{P}$ may influence PR dissolution products since the $\mathrm{P}$ released from PRs is effectively removed from solution by iron and aluminium oxides, thus, creating a gradient for further dissolution of the PR. The solubility product principle suggests that the imposed gradient by reaction products may become an effective driving force for the PR dissolution. Calcium is one of the products of PR dissolution which is released to the soil solution in amounts proportionate to the rate of $\mathrm{P}$ released.

Estimates of PR dissolution in soils traditionally have involved (i) the use of exchange resins of various forms (Amer et al., 1955), (ii) Bray-I extractable P, and (iii) measurement of compounds formed by secondary reactions of dissolved $\mathrm{P}$ such as Al- and Fe-P, and Ca-P in soils. Such $\mathrm{P}$ reaction products are measured by $0.1 M \mathrm{NaOH}$ for Al- and Fe-P and $1 \mathrm{M} \mathrm{HCl}$ extractions for Ca-P (Hedley et al., 1982). Few studies in Ghana have investigated the 
dissolution and amounts of plant-available $\mathrm{P}$ in soils to which PRs have been added. A better understanding of the reactions of PR in soils would be useful in assessing soils which could be suitable for PR application.

The objectives of the present study were (i) to assess the extent of dissolution of Togo rock phosphate (TRP), 50\% partially acidulated Togo rock phosphate (PAPR) and Gafsa rock phosphate added to the Bekwai, Nzima and Kokofu soils, and (ii) in a separate greenhouse experiment, determine the effectiveness of these $\mathrm{P}$ sources in the three benchmark soils using maize as a test crop.

Site characteristics and soils

\section{Materials and methods}

The study site was located near the University of Ghana Agricultural Research Centre (ARC) at Kade $\left(6^{\circ} 43^{\prime} \mathrm{N}: 1^{\circ} 36^{\prime} \mathrm{W}\right)$ in the Eastern Region of Ghana. The mean annual rainfall ranges from 1500 to $2000 \mathrm{~mm}$. The vegetation is mainly forest re-growth with Chromolaena odorata, Mimosa pudica and Centrosema pube-scense as major plant species. Surface soils $(0-20 \mathrm{~cm})$ of Bekwai, Nzima (paleudult) and Kokofu (paleudalf) were sampled from their respective profiles. Bekwai and Nzima were upland soils and Kokofu, a lowland soil. The bulk soil samples were transported to the laboratory, air-dried, crushed and passed through a $2 \mathrm{~mm}$ sieve to remove twigs, plant roots and ironstone concretions.

\section{Phosphorus sources}

Phosphorus fertilizer sources used for the laboratory incubation and greenhouse studies were Togo rock phosphate (TRP), Gafsa rock phosphate (GRP), 50\% partially acidulated Togo rock phosphate (PAPR) and triple superphosphate (TSP). Total $\mathrm{P}\left(\mathrm{P}_{\mathrm{T}}\right)$ of the $\mathrm{P}$ sources was determined after wet digestion using concentrated $\mathrm{HNO}_{3}-60 \% \mathrm{HClO}_{4}$ mixture. Neutral ammonium citrate (1 $N$ ) soluble $\mathrm{P}$ and $2 \%$ citric acid soluble $\mathrm{P}$ of the phosphorus fertilizers were also determined by shaking the soil samples in the respective extractants, and P in the extracts was measured using spectrophoto-meter at $712 \mathrm{~nm}$ following the procedure of Murphy \& Riley (1962).

\section{Laboratory analyses}

Particle size distribution was determined by the hydrometer method (Bouyoucous, 1962). Soil $p \mathrm{H}$ was determined using 1:2 soil:water ratio and also in $0.01 \mathrm{M} \mathrm{CaCl}_{2}$ suspension. Total carbon was determined by Walkley \& Black (1934) method and total $\mathrm{N}$ was determined by Kjeldhal method. Total $\mathrm{P}\left(\mathrm{P}_{\mathrm{T}}\right)$ of the soils was determined by a mixture of concentrated $\mathrm{HNO}_{3}-\mathrm{HClO}_{4}$ digestion as described by Sommers et al. (1970) and available P by Bray \& Kurtz (1945) method. Exchangeable cations $(\mathrm{Ca}, \mathrm{Mg}, \mathrm{K}$ and $\mathrm{Na})$ in the soils were extracted with $1 \mathrm{~N} \mathrm{NH}_{4} \mathrm{OAc}(p \mathrm{H} \mathrm{7.0)}$ and $\mathrm{Ca}$ and $\mathrm{Mg}$ were measured using atomic absorption spectrophotometer. Sodium and $\mathrm{K}$ were measured by flame photometer. Exchange-able acidity of the soils was determined by $0.1 \mathrm{~N}$ $\mathrm{NaOH}$ titration after extraction with $1 N \mathrm{KCl}$. Effective cation exchange capacity (ECEC) was calculated by summation of the basic cations and exchangeable acidity.

\section{Incubation study}

Two replicates of $200 \mathrm{~g}$ sieved $(<2 \mathrm{~mm})$ samples of Bekwai, Nzima and Kokofu soil were each weighed into $250 \mathrm{ml}$ plastic beakers. Weighed amounts of TRP, GRP, PAPR and TSP to supply $60 \mathrm{mg} \mathrm{P} \mathrm{kg}^{-1}$ were added to each of the soils in the beakers and then thoroughly mixed. A control treatment without $\mathrm{P}$ was included. Distilled water was added to each soil to bring it to $60 \%$ field capacity. The set up was incubated at room temperature for 105 days. To assess the reaction and, hence, the availability of the different $\mathrm{P}$ sources in the soil, sub-samples of the 
incubated soils were taken every 21 days (i.e. 21, 42, 63, 84 and 105 days) and analyzed for resin-P, Fe/Al-P and Ca-P as described below.

Resin-P was extracted using anion exchange resin membrane $(\mathrm{AEM})$. The AEM $(9 \times 62.5$ $\mathrm{mm}$ ) was charged by washing it for 3 days with several batches of $0.5 \mathrm{M} \mathrm{HCl}$ and finally rinsed with distilled water. The membranes were kept moist until ready to use.

A $0.5 \mathrm{~g}$ of the incubated soil was weighed into a $100-\mathrm{ml}$ plastic bottle, a resin strip was put into the plastic bottle and then $30 \mathrm{ml}$ of distilled water added. The plastic bottle was shaken for $16 \mathrm{~h}$ on an end-to-end mechanical shaker overnight at room temperature. The resin membranes were removed from the soil suspensions using forceps and then washed with distilled water to remove adhering soil particles. The soil suspension was then discarded and the bottles thoroughly washed. The resin strip membranes were placed in the clean bottles and $20 \mathrm{ml}$ of 0.5 $M \mathrm{HCl}$ was added. This was shaken for another $16 \mathrm{~h}$ overnight to release the soil phosphate held onto the membrane. A 5-ml aliquot of the extract was taken and the desorbed phosphate analyzed using the Murphy \& Riley (1962) method.

To determine Fe/Al-P in the incubated soils, $0.5 \mathrm{~g}$ of the soils was weighed into clean plastic bottles and $20 \mathrm{ml}$ of $0.5 \mathrm{M} \mathrm{NaOH}$ added. The suspension was shaken as described above and $\mathrm{P}$ in the extract measured. Similarly, Ca-P was determined by weighing $0.5 \mathrm{~g}$ of the incubated soil into plastic bottles, $20 \mathrm{ml}$ of $1 M \mathrm{HCl}$ was added and then shaken for $16 \mathrm{~h}$ and $\mathrm{P}$ in the extract determined.

\section{Greenhouse experiment}

The experimental design for the greenhouse study was a randomized complete block design involving the three soil series (Bekwai, Nzima and Kokofu), four P sources at a rate of $60 \mathrm{mg} \mathrm{P}$ $\mathrm{kg}^{-1}$ soil and a control. The experiment was replicated four times giving a total of 60 experimental units $(5$ Treatments $\times 3$ Soils $\times 4$ Reps). Equal amount $(1.5 \mathrm{~kg})$ of each soil was weighed into plastic pots and the P fertilizers (TRP, GRP, PAPR and TSP) were added at the rate of $60 \mathrm{mg} \mathrm{P} \mathrm{kg-}^{-1}$ soil. In adding the $\mathrm{P}$ sources, the soil in each pot was transferred into a large plastic basin and the weighed amount of the $\mathrm{P}$ source was added, thoroughly mixed and returned to the respective pots.

Four maize seeds were sown in each pot and distilled water was added to bring the soils to $60 \%$ field capacity. The blocks were rotated weekly to minimize uneven environmental effects within the greenhouse. The plants were thinned to two per pot 3 days after germination and were allowed to grow for 28 days. During harvesting, plants were cut at the soil surface and immediately weighed for the fresh weight. The plants were oven-dried at $70{ }^{\circ} \mathrm{C}$ to a constant weight. The dried plant materials were ground to pass through 1-mm sieve. One gram of each plant material was digested using $5 \mathrm{ml}$ of concentrated $\mathrm{H}_{2} \mathrm{SO}_{4}$ and $30 \% \mathrm{H}_{2} \mathrm{O}_{2}$ (Thomas et al., 1967). Phosphorus in the digest was determined by Murphy \& Riley (1962) method.

\section{General soil properties}

\section{Results and discussion}

Selected properties of the soils are shown in Table 1. Bekwai and Nzima (both Paleudult) and Kokofu series (Paleudalf) form part of catena of soils predominant in the semi-deciduous rainforest zone of Ghana. Properties of these soils included varying amounts of ironstone concretions (data not shown), a broad range of textural class (sandy clay loam to predominantly clay), low $p \mathrm{H}$ and low ECEC. The low $p \mathrm{H}$ implied that the PRs would dissolve fast in the soils. Levels of organic carbon (OC) ranged from 11.2 to $20.2 \mathrm{~g} \mathrm{~kg}^{-1}$. The total $\mathrm{N}$ corresponded with the amounts of $\mathrm{OC}$ of the soils. That is, the Bekwai soil with a high amount of OC also had high total $\mathrm{N}$ content and the Kokofu soil had the least OC and total N (Table 1). 
TABLE 1

Some selected physical and chemical properties of the soils

\begin{tabular}{|c|c|c|c|}
\hline Soil properties & Bekwaiup slope & Nzimaup slope & Kokofu lowland \\
\hline Sand $(\%)$ & 51.2 & 44.2 & 39.8 \\
\hline Silt (\%) & 14.2 & 21.0 & 24.2 \\
\hline Clay $(\%)$ & 34.6 & 34.8 & 36.0 \\
\hline Texture & $\mathrm{SCL}^{*}$ & $\mathrm{CL}^{* *}$ & $\mathrm{CL}^{* *}$ \\
\hline$p \mathrm{H}(1: 2$, soil : water $)$ & 5.4 & 5.2 & 4.9 \\
\hline$p \mathrm{H}\left(1: 2\right.$, soil : $\left.\mathrm{CaCl}_{2}\right)$ & 4.9 & 4.9 & 4.2 \\
\hline Organic carbon $\left(\mathrm{g} \mathrm{kg}^{-1}\right)$ & 20.2 & 13.8 & 11.2 \\
\hline Total N (g kg-1) & 2.2 & 1.8 & 1.5 \\
\hline Total P (mg kg-1) & 339 & 330 & 314 \\
\hline Available P (Bray $1 \mathrm{mg} \mathrm{kg-}^{1}$ ) & 3.48 & 2.50 & 3.16 \\
\hline $\mathrm{Ca}\left(\mathrm{cmolc} \mathrm{kg-}^{-1}\right)$ & 5.65 & 5.46 & 5.57 \\
\hline $\operatorname{Mg}\left(\right.$ cmolc kg- $\left.^{1}\right)$ & 1.54 & 1.47 & 1.52 \\
\hline $\mathrm{K}\left(\right.$ cmolc kg- $\left.^{-1}\right)$ & 0.08 & 0.34 & 0.18 \\
\hline $\mathrm{Na}\left(\mathrm{cmolc} \mathrm{kg-1}^{1}\right)$ & 0.52 & 0.31 & 0.49 \\
\hline Exchangeable acidity (cmolc kg- $\left.{ }^{-1}\right)$ & 0.30 & 0.27 & 0.50 \\
\hline $\left.\operatorname{ECEC~(cmolc~kg-~}{ }^{-1}\right)$ & 8.09 & 7.85 & 8.26 \\
\hline $\mathrm{Ca}: \mathrm{Mg}$ & 3.7 & 3.7 & 3.7 \\
\hline
\end{tabular}

Available P values were low for all the three soils which strongly suggested $\mathrm{P}$ deficiency in the soils and, hence, the need for fertilizer application (Mokwunye \& Bationo, 2002). Sahrawat et al. (1997) reported an extractable $\mathrm{P}$ of $12.5-15 \mathrm{mg} \mathrm{P} \mathrm{kg}^{-1}$ (Bray $1 \mathrm{P}$ ) as critical range for rice and, most likely, for other cereals. The low available $\mathrm{P}$ content of the soils, despite a high total $\mathrm{P}$, seemed to suggest that considerable proportion of the $\mathrm{P}$ was fixed and unavailable to plants. The exchange complex of the soils was dominated by $\mathrm{Ca}$ and $\mathrm{Mg}$ with $\mathrm{Ca}$ contributing about $50 \%$ to the ECEC. The mean Ca: $\mathrm{Mg}$ ratio of 3.7 of these soils was far below the critical value of 5.0 (Horvath \& Todd, 1968). Generally Ca: $\mathrm{Mg}$ ratio below 5.0 is an indication that $\mathrm{Ca}$ is more deficient than $\mathrm{Mg}$ in the soils.

\section{Resin extractable $P$}

The resin extractable $\mathrm{P}$ has been shown to be a useful index for estimating plant available $\mathrm{P}$ in soils to which PR materials have been added (Condron \& Goh, 1989). In general, the pattern of P extraction from the various $P$ sources can be categorized into three groups depending on the ease of $\mathrm{P}$ released. Category 1 which had the highest solubility was made up of TSP and PAPR, category 2 was GRP and was of medium solubility and category 3 was the least soluble and that was Togo RP. The amount of resin extractable $\mathrm{P}$ from all the $\mathrm{P}$ sources in the three soils decreased with incubation time (Fig. 1). The decrease was more obvious in Bekwai and Nzima soils than in the Kokofu soil. From the 12th to the 15th week, very low amount of $\mathrm{P}$ was extracted from all the P sources, indicating that less P remained in the soil for plant uptake within that period. 

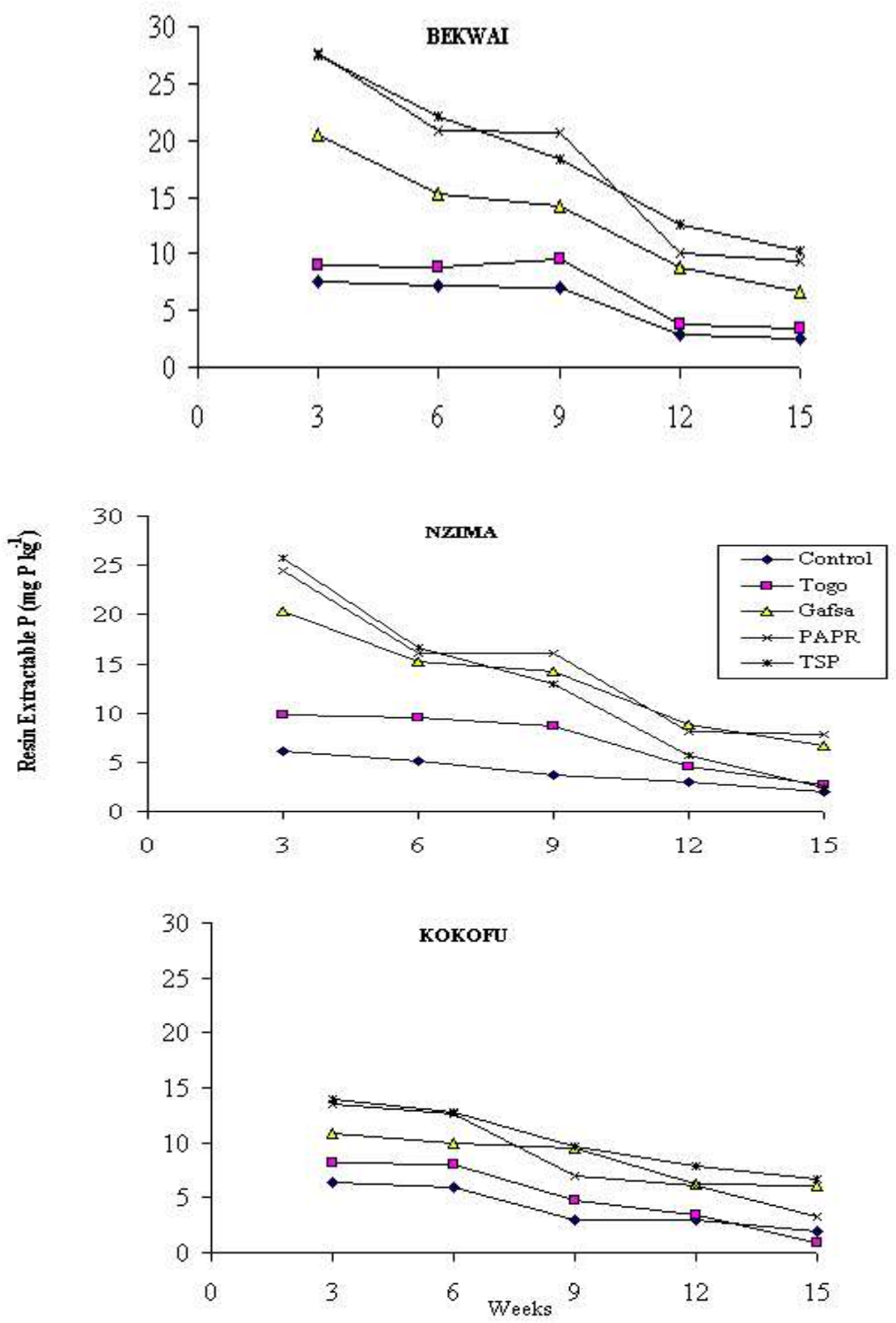

Fig. 1. Resin extractable $P$ mg kg-1 of the various $P$ sources during incubation

In the Kokofu soil, differences in P dissolution among the rock phosphates were slight with increasing incubation period compared to the two upland soils, Bekwai and Nzima (Fig. 1). The decrease in resin $\mathrm{P}$ was more gradual with time in the Kokofu soil. This trend tallied with that reported by Mackenzie (1971) when monocalcium phosphate was added to Ultisols and incubated at room temperature in a time series experiment. In the three soils, the least amount of resin extractable P released was obtained in the Kokofu soil. This may be attributed to the higher clay content in the Kokofu soil than in Bekwai and Nzima soils. Soil constituents responsible for $\mathrm{P}$ adsorption have been shown to be associated more with clay (Owusu-Bennoah \& Acquaye, 1989; Abekoe \& Sahrawat, 2001). The amounts of resin P extracted from TSP, PAPR and GRP 
were higher than that from TRP, a trend which followed the solubility characteristics of the P sources (Table 2).

TABLE 2

Total Phosphorus $(P)$ and extractable P contents of the various $P$ sources.

Phosphorus sources

Togo rock phosphate (TRP)

Gafsa rock phosphate(GRP)

Partially acidulated Togo rock phosphate(PAPR)

Triple superphosphate(TSP)

\begin{tabular}{|c|c|c|}
\hline & $P$ extracted by & \\
\hline otal P (\%) & $2 \%$ Citric acid & $\begin{array}{l}\text { Neutral ammonium } \\
\text { citrate } \% \mathrm{w} / \mathrm{w}\end{array}$ \\
\hline
\end{tabular}

$16.5 \quad 4.3 \quad 0.9$

$\begin{array}{lll}13.2 & 6.3 & 2.2\end{array}$

$12.0 \quad 10.0 \quad 10.2$

$\begin{array}{lll}20.0 & 18.4 & 18.1\end{array}$

\section{$0.1 \mathrm{M} \mathrm{NaOH}$ extractable-P}

$0.1 M \mathrm{NaOH}$ solution extracts adsorbed $\mathrm{P}$ that is bound to $\mathrm{Fe}$ and $\mathrm{Al}$ oxides in soils (Williams et al., 1971). Therefore, an increase in $\mathrm{NaOH}$-extractable $\mathrm{P}$ in a soil to which $\mathrm{PR}$ is added provides a good estimate of the amount of $\mathrm{P}$ dissolved and retained by the soil (Hanafi \& Syers, 1994). The amount of NaOH-P extracted was different in the three soils (Fig. 2). In the Bekwai and Nzima soils, there was a general increase in $\mathrm{NaOH}-\mathrm{P}$ from the $3 \mathrm{rd}$ to the 15 th week. The increase in NaOH-P may be due to $\mathrm{P}$ adsorbed onto $\mathrm{Fe}$ and $\mathrm{A} 1$ oxides as the phosphate rocks dissolve to release $\mathrm{P}$ (Fig. 1 and 2). The NaOH-P extracted from TSP in the three soils was always higher than those from the other P sources due to the high solubility and availability of the water soluble commercial fertilizer, TSP. The amount of NaOH-P extracted from the Togo PR with time was generally much greater than in the control.

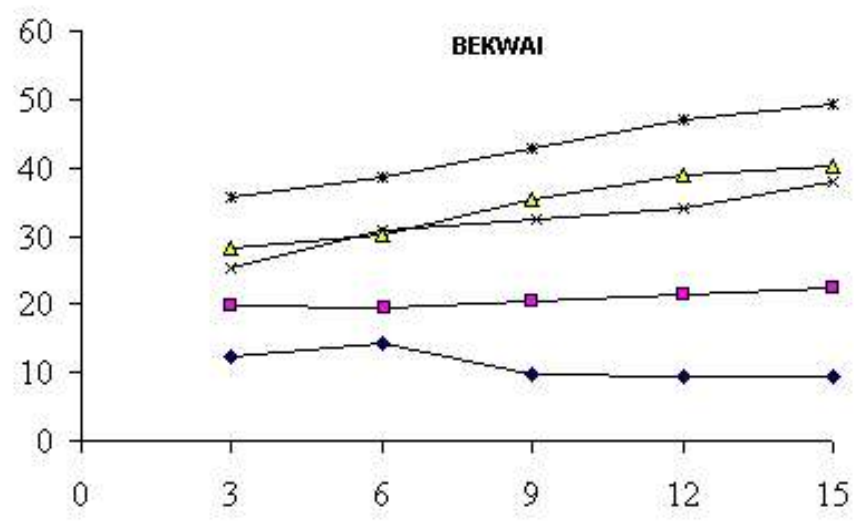



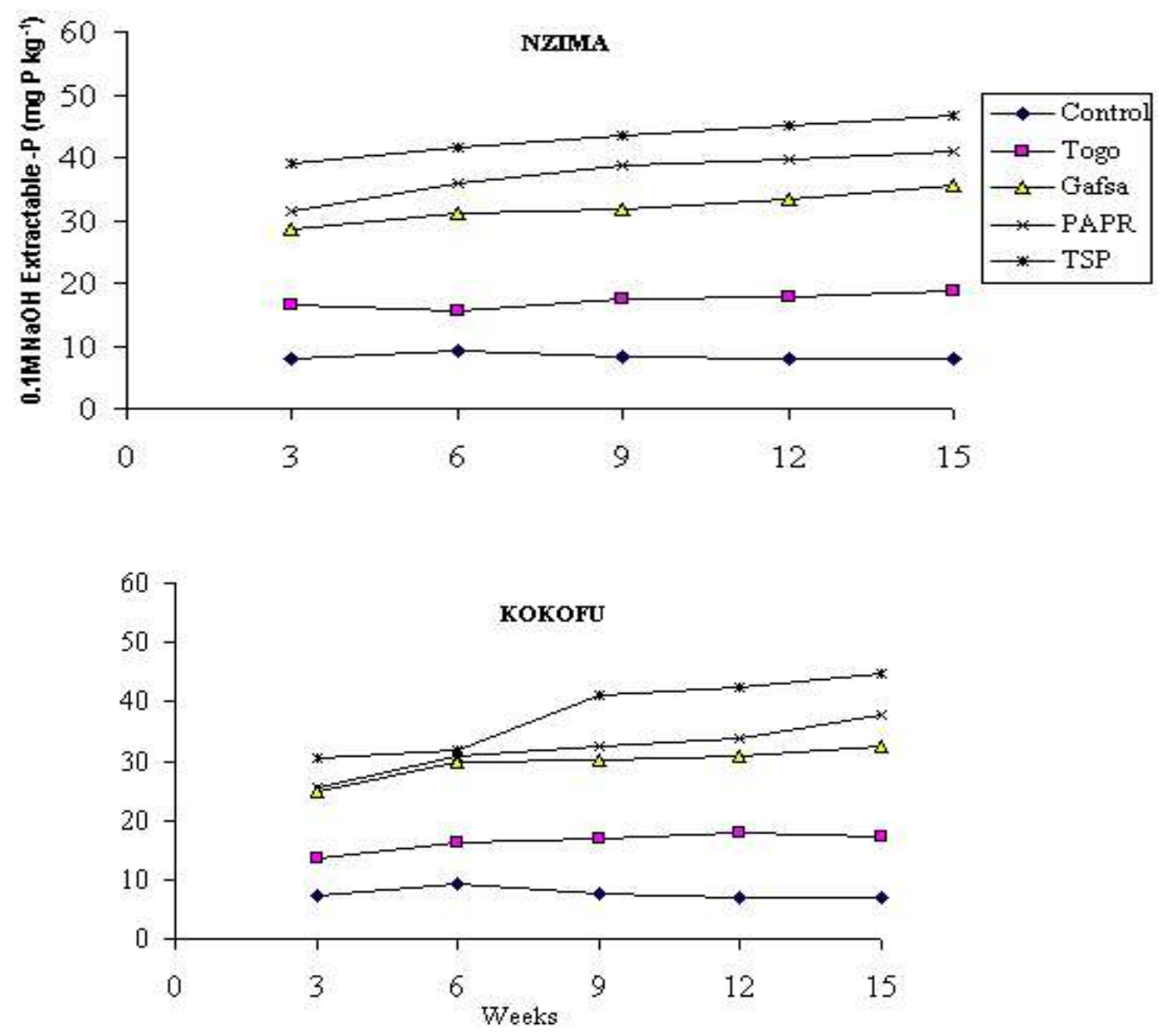

Fig. 2. 0.1 $M$ NaOH extractable $P$ mg kg-1 of the various $P$ sources during incubation

There was a gradual increase of NaOH-P extracted from the 3rd to the 15th week in the Kokofu soil as well. The increase in NaOH-P extracted with time in soils has been reported by other workers (Mackay et al., 1984; Hanafi \& Syers, 1994). In the Kokofu soil also, the $0.1 \mathrm{M}$ $\mathrm{NaOH}-\mathrm{P}$ fraction from TSP was more than the other P sources, suggesting that most of the soluble $\mathrm{P}$ released from it is converted to adsorbed $\mathrm{P}$ associated with Fe and A1 (Sample et. al., 1980; Condron \& Goh, 1989).

\section{M HCI extractable- $P$}

$1 M$ HCI extractable P represents the amount of Ca-P in the PR that remained undissolved. The $\mathrm{HCl}$ extractable $\mathrm{P}$ decreased with time (Fig. 3), suggesting the dissolution of the $\mathrm{P}$ sources in the soils. At each incubation period the amount of HCI-P extracted from TRP was similar to those from the other $\mathrm{P}$ sources. In general, there was no marked difference among the $\mathrm{P}$ sources with respect to $\mathrm{HCI}$ extractable $\mathrm{P}$. 


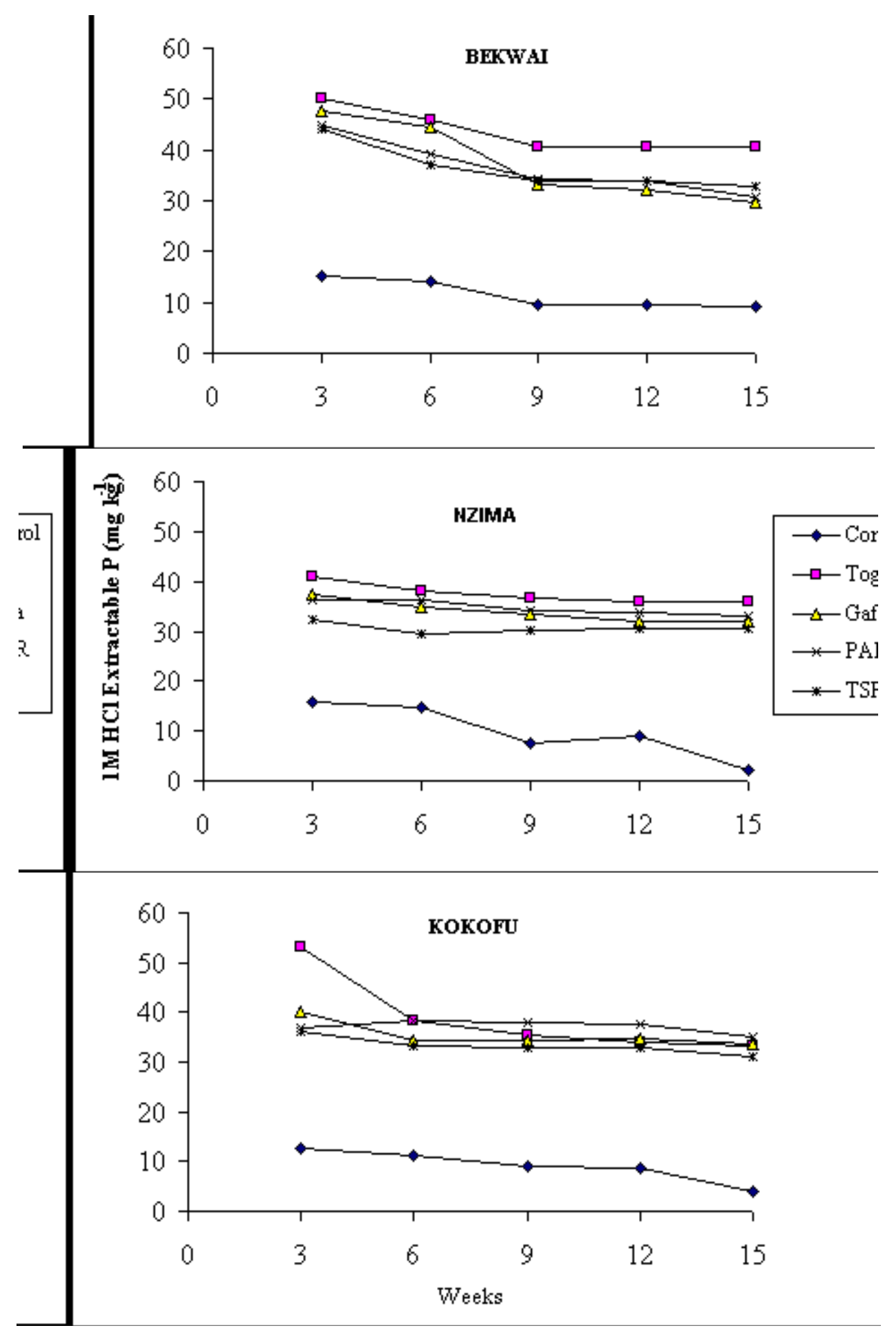

Fig. 3. $1 M \mathrm{HCl}$ extractable $P \mathrm{mg} \mathrm{mg} \mathrm{kg}^{-1}$ of the various $P$ sources during Incubation

\section{Greenhouse experiment}

In the greenhouse experiment the maize crop responded to the application of the $\mathrm{P}$ amendments, especially TSP, PAPR and GRP (Table 3 ). The variation in yield due to P sources was statistically significant $(P<0.05)$. Similar to the results of the incubation study, the dry 
matter yield (DMY) of the maize crop may be grouped into three categories; TSP and PAPR treated (category I) giving the highest yield, followed by GRP (category 2), and the TRP treated soils (category 3), gave the least DMY of maize shoot. Dry matter yields obtained from GRP were found to be significant in all the three soils with respect to the TRP. Leon et al. (1986) suggested that GRP is more available to plants than many phosphate rocks. These results are consistent with the solubility properties of the P sources (Table 2). Triple superphosphate had the highest neutral ammonium citrate soluble P $(18.1 \%)$ whereas TRP had the least. This, therefore, explains why TSP gave the highest DMY of shoot in all the soils, while TRP gave the least. The increased growth may be attributed to improved uptake of $\mathrm{P}$ from the soils by the test crop. The DMY for TRP was similar to the control treatment signifying the low reactivity of the Togo rock phosphate.

TABLE 3

Effect of P source on the yield, total P uptake of shoot and relative agronomic efficiency of the P sources in Bekwai, Nzima and Kokofu soils for the Greenhouse study.

\begin{tabular}{|c|c|c|c|}
\hline P source & $\begin{array}{l}\text { Fresh shoot weight } \\
\qquad \text { g plant }^{-1}\end{array}$ & $\begin{array}{l}\text { Dry shoot weight } \\
\qquad \text { g plant }^{-1}\end{array}$ & $\begin{array}{c}\text { Total P- Uptakeof shoot } \\
\text { mg P plant- }{ }^{I}\end{array}$ \\
\hline \multicolumn{4}{|c|}{ Bekwai } \\
\hline Control & $31.26 \mathrm{c}$ & $3.59 \mathrm{c}$ & $8.82 \mathrm{c}$ \\
\hline Togo RP & $33.22 \mathrm{c}$ & $3.82 \mathrm{c}$ & $9.78 \mathrm{c}$ \\
\hline GAFSA RP & $40.30 \mathrm{~b}$ & $4.86 \mathrm{~b}$ & $13.39 b$ \\
\hline PAPR-50 & $44.10 \mathrm{a}$ & $5.86 \mathrm{a}$ & $21.37 \mathrm{a}$ \\
\hline TSP & $45.90 \mathrm{a}$ & $6.32 \mathrm{a}$ & $23.58 \mathrm{a}$ \\
\hline LSD (0.05) & 2.47 & 0.71 & 2.85 \\
\hline CV (\%) & 4.12 & 9.51 & 12.0 \\
\hline \multicolumn{4}{|c|}{ Nzima } \\
\hline Control & $22.70 \mathrm{c}$ & $2.15 c$ & $4.65 c$ \\
\hline Togo RP & $25.10 \mathrm{c}$ & $2.41 \mathrm{c}$ & $5.59 \mathrm{c}$ \\
\hline GAFSA RP & $31.63 b$ & $3.58 \mathrm{~b}$ & $8.93 b$ \\
\hline PAPR-50 & $37.93 a$ & $5.40 \mathrm{a}$ & $17.26 \mathrm{a}$ \\
\hline TSP & $42.11 \mathrm{a}$ & $5.46 \mathrm{a}$ & $18.19 \mathrm{a}$ \\
\hline LSD (p 0.05) & 4.26 & 1.46 & 1.46 \\
\hline CV (\%) & 8.68 & 9.26 & 15.1 \\
\hline \multicolumn{4}{|c|}{ Kokofu } \\
\hline Control & $22.70 \mathrm{c}$ & $2.35 \mathrm{c}$ & $4.51 \mathrm{c}$ \\
\hline Togo RP & $25.58 \mathrm{c}$ & $2.38 \mathrm{c}$ & $5.27 \mathrm{c}$ \\
\hline GAFSA RP & $29.33 b$ & $3.59 \mathrm{~b}$ & $9.98 b$ \\
\hline PAPR-50 & $35.58 \mathrm{a}$ & $4.27 \mathrm{a}$ & $14.67 \mathrm{a}$ \\
\hline TSP & $37.85 \mathrm{a}$ & $4.38 \mathrm{a}$ & $15.42 \mathrm{a}$ \\
\hline LSD (p 0.05) & 4.67 & 0.42 & 1.51 \\
\hline CV $(\%)$ & 9.60 & 8.12 & 9.81 \\
\hline
\end{tabular}

$(\mathrm{DMY})=$ Dry shoot weight; P-UP $=$ Total P-uptake of shoot.

Figures in the same column followed by the same letter are not significantly different.

In terms of P-uptake, there was no significant difference between TSP and PAPR treatments. Total P-uptake from GRP was lower than those from TSP and PAPR. Total P-uptake from TRP and control was found to be similar in all the soils (Table 3). In general, the variations in Puptake followed closely those of the dry matter yield. Similar results have been reported by Owusu-Bennoah \& Acquaye (1996), Bationo et al. (1986) and Hammond et al. (1986b). 
Mokwunye \& Pinto-Toye (1999) also reported that finely ground untreated TRP gave lower yields than TSP and PAPR, the latter two were equal in effectiveness. Chien \& Menon (1993b) attributed this observation to the "starter effect" of the water soluble component of the PAPR. The authors emphasized that PAPR is essentially a mixture of monocalcium phosphate (MCP) and raw PR, and that the water soluble P component encourages early plant root development. In all, the results from the greenhouse study clearly indicated that the potential of untreated Togo rock phosphate for direct application was low in the three soils studied.

\section{Conclusion}

Bekwai, Nzima and Kokofu soils are inherently low in P supplying capacity as indicated by their Bray $1 \mathrm{P}$ levels. These soils, therefore, require $\mathrm{P}$ fertilizers to increase crop production. The results from the incubation studies and the greenhouse experiment showed that TSP, PAPR and GRP were more soluble than the untreated TRP. Togo rock phosphate was, therefore, inferior to the other $\mathrm{P}$ sources in increasing dry matter yield and $\mathrm{P}$ uptake of maize in the three soils. Relative to TSP, 50\% partially acidulated Togo rock phosphate (PAPR) was reactive enough in the soils to provide plant available $\mathrm{P}$ to satisfy the early $\mathrm{P}$ requirement for maize growth. Raw TRP has very little potential for direct application in the soils studied but when acidulated, its effectiveness as $\mathrm{P}$ fertilizer is enhanced.

\section{References}

Abekoe M. K. and Sahrawat K. L (2001). Phosphate retention and extractability in soils of the humid zone in West Africa. Geoderma 102: 175-187.

Amer F., Bouldin D. R., Black C. A. and Duke F. R. (1955). Characterization of soil phosphorus by anion exchange resin adsorption and 32P equilibration. Pl. Soil 6: 391-408

Bationo A., Mughogho S. K. and Mokwunye A. U. (1986). Agronomic evaluation of phosphate fertilizers in tropical Africa. In Management of Nitrogen and Phosphorus Fertilizers in sub-Saharan Africa. (A. U. Mokwunye and P. L. G. Vlek, ed.), pp. 283-318. Martinus Nijhoff Publishers, Dordrecht, The Netherlands.

Bouyoucos G. J. (1962). Hydrometer method improved for making particle size analyses of soils. Agron. J. 54: 464465.

Bray R. H. and Kurtz L. T. (1945). Determination of total organic and available forms of phosphorus in soils. Soil Sci. 59:39-45.

Chien S. H. and Menon R. G. (1993b). Agronomic evaluation of modified phosphate rock products: IFDC's Experience. Research and Development Division, IFDC, Muscle Shoals, Alabama.

Condron. L. M. and Goh K. M. (1989). Effects of long-term phosphatic fertilizer applications on amounts and forms of phosphorus in soils under irregular pasture in New Zealand J.Soil Sci. 46: 383-395.

Hammond L. L. Chien S. H and. Mokwunye A. U (1986b). Agronomic value of unacidulated and partially acidulated phosphate rocks indigenous to the tropics. Adv. Agron. 40: 89-140.

Hanafi M. M. and. Syers J. K. (1994). Plant availability of two phosphate rock materials in acid malaysion soils. Commonw. Soil Sci. Pl. Anal. 25: 3171-3189.

Hedley M. J., Stewart, J. W. B. and Chauban B. S. (1982a). Changes in inorganic soil phosphorus fractions induced by cultivation practices and by laboratory incubations. Soil Sci. Soc. Am. J. 46: 970-976.

Horvath D. J. and Todd J. R. (1968). Magnesium supplements for cattle. In Proc. 23rd Annual Texas, Nutrition Conference, pp. 96-104.

Khasawneh F. E. and Doll E. C (1978). The use of phosphorus rock for direct application to soils. Adv. Agron. 30: 159-206.

Leon L. A., Fenster W. E and Hammond L. L. (1986). Agronomic potential of eleven phosphates rocks from Brazil, Colombia, Perv and Venezuela. Soil Sci. Soc. Am. J. 50: 798-802.

McClellan G. H and Notholt A. J. K. (1986). Phosphate deposits of tropical sub-Saharan Africa, In Management of Nitrogen and Phosphorus Fertilizers in sub-Saharan Africa. (A.U Mokwunye and P. L. G. Vlek, ed.), pp. 173-223. Martinus Nijhoff Publishers, Dordrecht, The Netherlands.

Mackay A. D., Syers J. K, Tillman A. W, and Gregg P. E. H. (1984a). A simple model to describe the dissolution of phospate rock materials in soil. Sci. Soc. Am. J. 50: 291-296.

Mokwunye A. U. and Bationo A. (2002). Meeting the phosphorus needs of the soils and crops of West Africa: the role of indigenous phosphate Rocks: In Integrated Plant Nutrition Management in sub-Saharan Africa. pp. 209234. 
Mokwunye A.U. and Pinto-Toyi. A. K (1999). Efficient fertilizer use for increased crop production: The IFD-Africa experience. In Alleviating soil fertility constraints to increase crop production in West Africa. (A. U. Mokwunye, ed.), pp. 235-244. Kluwer Academic Publishers, Dordrecht, The Nethelands.

Murphy J. and Riley J. P. (1962). A modified single solution method for the determination of phosphorus in natural waters. Anal. Chim. Acta 27: 31-36.

Owusu-Bennoah E., Awadzi T. W. A., Boateng E, Krogh H., Madsen B. and Borggard O. K. (2000). Soil properties of a toposequence in the moist semi-deciduous forest zone of Ghana. W. Afr. J. appl. Ecol. 1: 1-10.

Owusu-Bennoah E. and D. K. Acquaye (1989). Phosphate sorption characteristics of selected major Ghanaian soils. Soil Sci. 148: 114-123

Owusu-Bennoah E. and Acquaye D. K, (1996). Greenhouse evaluation of agronomic potential of different sources of phosphate fertilizer in a typical concretionary soil of northern Ghana. Fert. Res. 10: 16.

Sahrawat K. L., Jones M. P. and Diatta S. (1997). Extractable phosphorus and rice yield in an Ultisol of the humid forest zone of West Africa. Commonw. Soil Sci. Pl. Anal. 28(9 \& 10): 711-716.

Sale P. W. G. and Mokwunye A. U. (1993). Use of phosphate rocks in the rotpics. Fert. Res. 35: 33-45.

Sample E. C., Super R. J and Racz G. J. (1980). Reactions of phosphate fertilizers in soils. In The Role of Phosphorus in Agriculture. (F. E. Khasawneh, E. C. Sample and E. J. Kamprath, ed.), pp. 263-304 .ASA, CSAA, SSSA. Madison, Wisconsin, USA.

Smyth J. J. and Sanchez P. A. (1982). Phosphate rock dissolution and availability in Cerrado soils as affected by P sorption capacity. Soil Sci. Soc. Am. J. 46: 330-345.

Sommers L. E., Harris Williams J. D. H., Armstrong D. E and Syers J. K. (1970). Determination of total organic Phosphate in lake sediments. Limnol. Oceanogr. 15: 301-304.

Thomas R. L., Sheard W. W. and Moyer J. R. (1967). Comparison of conventional automated procedures of N. P and K. analysis of plant materials using a single digestion. Agron. J. 59: 240-243.

Walkley A. and Black I. A. (1934). An examination of the Dehtjareff method for determining soils organic matter and a proposed modification of the chromic acid titration method. Soil Sci. 37: 29-38.

Williams J. D. H., Syers S. K. Harris R. F. and. Armstrong, D. E. (1971). Fractionation of inorganic phosphate in calcareous lake sediments. Soil Sci. Soc. Am. Proc. 35: 250-255. 